\title{
Politik Tubuh Perempuan: Studi Tes Genitalia pada Perekrutan Anggota Polisi Baru di Indonesia
}

\author{
Abdul Azis Pratama \\ Program Studi Ilmu Pemerintahan, Universitas Sultan Ageng Tirtayasa \\ Email : aazizpratama@gmail.com
}

\begin{abstract}
The focus of this research is to see how Body, Sex, and Norm play a role in Women's Subjugation in Indonesia. As a conservative and moslem majority country, Indonesia often find herself strangled in Sexist Situation. Whereas Men had been granted a greater role in public affairs, and more excepted to be a leader, than its companion gender. Besides of not having the same opportunity as men in public affairs, Women in Indonesia also faced a subjugation of their body and their 'morale'. It is said, that one of the Indonesian norm is to forbids Women to having a pre-marital sex, and to do so they have to covering their bodies, and not to be too friendly to Male Strangers. However, this standard doesnt apply to Men, which leads to a situation where Women's become a more inferior gender in terms of personal expression. But the problem didn't stop there, Women who caught already have a pre-marital sex (determined by the intactness of Hymen) will faced another discrimination, such as social judgement, excommunication and exclusion in several employment, for Instance in Kepolisian Republik Indonesia (Indonesian Police Force).
\end{abstract}

Keywords: women, virginity, hymen, POLRI, politic of body.

\begin{abstract}
Abstrak
Fokus penelitian ini adalah untuk melihat bagaimana politik tubuh, jenis kelamin dan norma yang berperan dalam seleksi masuk kepolisian indonesia. Sebagai negara mayoritas yang konservatif dan mayoritas beragama Islam, Indonesia sering menemukan posisi-posisi yang menyudutkan perempuan dalam Situasi yang tidak setara. Sedangkan Pria telah diberikan peran yang lebih besar dalam urusan publik, dan lebih dikecualikan untuk menjadi pemimpin, daripada gender pendampingnya. Selain tidak memiliki kesempatan yang sama dengan laki-laki dalam urusan publik, Perempuan di Indonesia juga menghadapi penaklukan tubuh dan 'moral' mereka. Penelitian ini mengelaborasi mengenai posisi perempuan dalam seleksi menjadi anggota polri, dima tubuh mereka menjadi sebuah objek yang harus dijaga dalam sebuah status keperawanan. Riset ini juga melihat bagaimana isu yang berkembang dalam tes kesehatan yang melihat lebih jauh tubuh perempuan sebagai objek yang
\end{abstract}


harus di jaga. Dengan pendekatan fenomenologi, riset ini akan lebih mengelaborasi segala objektifikasi terhadap tubuh perempuan.

Kata kunci: perempuan, keperawanan, selaput dara, POLRI, politik tubuh.

\section{Pendahuluan}

Di Indonesia, pemahaman terhadap identitas perempuan sifatnya sangat beragam tergantung pada suku, kelas sosial dan agama yang ada, namun secara umum, perempuan selalu pertama-tama dan terutama diharapkan menjadi ibu serta isteri (Suryakusuma, 2012:113). Hal ini terbentuk atas dasar konstruksi gender pada perkembangan peran perempuan di masyarakat. Pada masyarakat Jawa misalnya, yang mengenal istilah 'konco wingking' yang berarti teman belakang, dalam hal menyebut peran perempuan. 'Teman belakang' disini kerap diasosiasikan sebagai bentuk ketidaksamarataan laki-laki yang berada di depan dengan perempuan yang dibelakang.

Posisi perempuan yang 'di belakang', ditunjukkan pada perannya di rumah tangga seperti kasur (reproduksi), dapur (memasak), dan sumur (membersihkan). Setelah itu budaya Jawa juga menekankan kembali tugas perempuan yang hampir sama pada perannya tadi, yang berupa macak (berhias), manak (reproduksi), dan masak.

Kebiasaan ini berlarut-larut akan menjadikan perempuan terdomestifikasi dibanding laki-laki. Perempuan dituntut, secara sosial, budaya, serta adat untuk berdiam di rumah dan melakukan tugas rumah tangga. Sehingga perempuan terpaksa untuk tidak dapat meluangkan waktu pada hal-hal yang progresif, baik keperempuanan secara indivdu, maupun secara kelompok. Sayangnya, hal ini tidak hanya dilakukan oleh lingkungan sosial yang ada, namun juga terbantu oleh sistem kenegaraan kita.

Menyimpulkan dari buku Suryakusuma (2012:114), yang menyatakan bahwa domestifikasi perempuan di Indonesia bersifat secara struktural karena disokong oleh negara, sejak jaman kita merdeka. Pada era demokrasi terpimpin era presiden Soekarno, organisasi keperempuanan serta ikatan-ikatan istri mulai dikembangkan 
pemerintah, yang bertujuan untuk mensuksesi program-program pemerintah pada perempuan melalui istri-istri pejabat. Pada era orde baru, praktik-pratik tersebut semakin terinstituisionalisasi. Demi membentuk perempuan Indonesia yang terdomestikatisasi dengan perannya sebagai 'pendamping' laki-laki (suami), pembawa keturunan dan pendidik bagi anak-anak, pengelola rumah tangga, pencari nafkah, dan baru akhirnya sebagai anggota masyarakat; dogma ini pada era orde baru disebut sebagai Panca Dharma Wanita.

Dapat dilihat pada Panca Dharma Wanita, peran perempuan yang pertama adalah pendamping suami, dan baru terkahir perempuan berperan sebagai anggota masyarakat. Artinya terdapat upaya dari pemerintah untuk membungkam perempuan pada ranah publik. Dan hal ini secara signifikan semakin menekan kapabilitas perempuan serta perannya pada lingkungan, di luar urusan rumah tangga.

Selain dari persepsi sosial dan politis, Perempuan Indonesia juga kerap dipandang menggunakan kaca mata agama. Khususnya agama yang menjadi mayoritas di Indonesia, yaitu Islam. Islam memandang perempuan sebagai sebuah entitas pelengkap dalam hidup manusia. Hal ini mengakar dari kepercayaan Abrahamik, bahwa Perempuan diyakini berasal dari tulang rusuk Adam, manusia pertama, yang diciptakan Tuhan (Allah) untuk senantiasa menemani Adam, dan menjadi cinta milik Adam.

Islam memandang perempuan dengan mulia, tidak merendahkan perempuan atas laki-laki ataupun mendegradasikan martabat perempuan; namun kemuliaan yang diberikan kepada perempuan tidak didapat dengan cara cuma-cuma. Pada kepercayaan Islam, dan Abrahamik, Perempuan dianggap sebagai gender yang suci, karena perannya yang vital dalam membangun keluarga, dan membina anak-anak. Kesucian pada perempuan ini pun bersifat seperti dua ujung mata tombak, di satu sisi perempuan mendapat peran yang khusus di masyarakat, dan di akhirat kelak, tapi di sisi lain konsep kesucian kadang kala digunakan untuk membungkam perempuan itu sendiri.

Kesucian Perempuan kerap dimanifestasikan sebagai objek yang sakral, perempuan, jiwa dan tubuhnya adalah sebuah hal yang sangat rapuh namun indah. 
Sehingga untuk menjaga kerapuhannya, perempuan kerap didomestikasikan. Perempuan akan diperintah untuk tetap di rumah, tidak keluar pada malam hari kecuali ditemani oleh mahram laki-lakinya, hingga untuk menutup aurat, demi menjaga kesucian yang dimilikinya.

Beberapa indikator kesucian yang dilekatkan pada diri perempuan adalah, sifatnya, imannya, hingga hymennya. Perempuan yang suci adalah perempuan yang patuh pada ayah dan suaminya, taat pada Tuhannya, dan dapat menjaga hawa nafsunya. Di luar daripada itu perempuan akan distempel dengan anggapan tidak suci dan akan terancam mendapat hukuman yang pedih di akhirat, serta bukan contoh yang baik di muka masyarakat. Salah satu problematika dari realita ini adalah digunakannya standar 'keperawanan' sebagai tanda moralitas perempuan.

Keperawanan merupakan sebuah konsep yang menyatakan sudah atau belumnya seseorang melakukan hubungan seksual, atas dasar keutuhan selaput dara (hymen) orang tersebut. Meskipun menurut catatan medis, tidak ada kesinambungan antara keutuhan selaput dara dengan pengalaman seksual seseorang (Cinthio, 2000: 172).

Konsep keperawanan menurut Kamm (2016: 83), merupakan sebuah konstruksi sosial, yang artinya ada kemungkinan tendensi konsep ini untuk menjadi unik dari satu tempat dengan tempat yang lainnya; tergantung pada bagaimana struktur sosial itu dibangun, dengan bentuk justifikasi yang paling umum adalah keperawanan diartikan sebagai harga diri dan martabat, bukan hanya teruntuk perempuan tersebut namun juga keluarga, suami, bahkan komunitasnya.

Dan parahnya, konsep sosial ini bukan hanya berlaku di masyrakat umum saja namun juga, rumornya, digunakan oleh Institusi negara seperti Kepolisian Republik Indonesia. Sesuai dari laporan HRW pada tahun 2014, bahwasanyna tiap tahun, Kepolisian melakukan pengecekan keperawanan pada calon anggota perwira perwira perempuan Polri. Dan tentu saja, hal ini sifatnya sangat diskriminatif dan tidak ramah gender. 


\section{Kerangka Teori}

\section{Politik Tubuh, Feminisme Sebagai Sebuah Kajian}

Mengutip Vrinda Varnekar, seorang akademisi feminis, dalam opinionfront.com (2018); menyatakan bahwa istilah 'feminis' pertama kali dikemukakan oleh filsuf berkewarganegaraan Perancis, Charles Fourier (1837) untuk merujuk pada konsep keadilan yang memandang kesamaan (equality) antar gender. Konsep ini nyatanya sudah ada telah lama, berbarengan dengan masa diskriminasi berbasis gender dimulai di dunia, namun oleh Fourier, ide ini dirubah untuk menjadi konsep kesatuan yang nantinya akan menyebar luas se-antero Perancis dan menjadi rujukan awal studi atas gender di Eropa.

Tujuan awal Feminisme yang diteken pada abad 18 adalah untuk menuntut tercapainya keadilan gender pada ranah-ranah publik dan privat semisal pada urusan politik, ekonomi, budaya, dan hak-hak fundamental lainnya. Tuntutan ini merupakan sebuah hasil dari perjalanan panjang opresi terhadap perempuan. Fakih (2013:12-13) memanifestasikan ketidakadilan gender ini sebagai bentuk pada ketidakadilan marginalisasi atau proses pemiskinan ekonomi, subordinasi atau anggapan tidak penting dalam keputusan politik, pembentukan strotype atau melalui pelabelan negatif, kekerasan (violence), beban kerja lebih panjang dan lebih banyak (burden), serta sosialisasi ideologi nilai peran gender (Hikmawan, 2017b).

Ide mengenai keadilan berbasis gender ini, pada masa modern sudah tertransformasikan keberbagai bentuk; hal ini dilandaskan pada kedinamisan serta keterbukaan individu atas spektrum politik mana yang mereka emban (Hikmawan, 2017a). Namun, perbedaan pandangan politik ini tidak akan menyerahkan ambisi utama gerakan feminis, yaitu keadilan atas perempuan.

Feminisme Liberal, feminisime liberal kerap dikaitkan dengan feminisme ortodoks dimana tujuan utamanya adalah menuntut keadilan gender melalui reformasi sosial, politik, hingga hukum. Terminasi dari keadilan pada feminisme liberal merupakan pemberian hak penuh dan menyeluruh pada perempuan, salah satunya adalah hak tentang aborsi;

Feminisme Radikal, sesuai dengan namanya feminis radikal menuntut reformasi sosial menggunakan cara yang relatif ekstrim. Feminis radikal percaya 
bahwa keadaan ketidakadilan pada masa sekarang, disebabkan oleh budaya patriarki yang telah mengakar. Sehingga Feminis Radikal percaya untuk menuntaskan ketidakadilan gender ini, diperlukan cara yang bersifat menyeluruh, yakni merekonstruksi tatanan sosial yang telah ada;

Feminisme Budaya, feminis budaya memaknai penyelesaian masalah ketidakadilan gender masa ini adalah melalui pendekatan alam dan kultur. Mereka menekankan bahwa asimilasi peran dan fungsi antar gender diperlukan demi terwujudnya dunia yang lebih seimbang;

Feminisme Sosialis dan Marxist, tipe feminis ini hadir dari ide mengenai sosialisme, dan marxisme yang digabungkan dengan konsep-konsep feminisme. Feminisme jenis ini menyatakan bahwa akar ketidakadilan di dunia, termasuk gender, adalah adanya kelas sosial. Kelas sosial yang dimaksud merupakan kelas sosial yang dibedakan lewat strata ekonomi. Maka dengan meniadakan kelas sosial ini, feminis sosialis percaya ketidakadilan gender juga akan hilang;

Ekofeminisme, sama seperti feminis sosialis, ekofeminisme juga merupakan gabungan dari dua cabang ide, yakni ekologi (ide tentang alam) dan feminisme. Ekofeminis percaya bahwa kerusakan alam dan opresi terhadap perempuan secara simbolis saling berkaitan. Semisal, laki-laki mengontrol dan merusak alam demi kepentingan mereka sendiri, sama seperti mereka 'mengontrol' dan 'merusak' perempuan

\section{Metode Penelitian}

Tipe penelitian dalam penelitian ini adalah penelitian kualitatif dengan pendekatan fenomenologi. Pendekatan fenomenologi, digolongkan ke dalam kelompok naturalistic inquiry, yakni metode penelitian yang memerlukan peran manusia sebagai instrumen penelitiannya. Atas dasar penelitian yang sarat akan muatan manusiawi (Hikmawan, 2014). peneliti dituntut untuk sepenuhnya memahami serta bersikap adaptif terhadap situasi sosial yang akan dihadapi pada isu tersebut (Garna, 2009: 38-39). Dalam hal ini, peneliti diwajibkan untuk menguasai situasi sosial di lingkungan Kepolisian Republik Indonesia serta juga 
situasi fisik dan psikis peserta calon perwira perempuan yang telah mengikuti tes keperawanan pada masa rekrutmennya.

Wawancara merupakan sebuah teknik pengumpulan data yang dalam praktiknya bertumpu pada kegiatan tanya-jawab, baik secara lisan maupun nonlisan, guna mendapat jawaban-jawaban penelitian. Menurut Creswel (2017: 256), teknik pengumpulan data dengan teknik wawancara bermanfaat untuk penelitian yang mencari data primer dan langsung, serta data yang didapat memungkinkan untuk memberikan kesan personal dan historis. Pada penelitian ini peneliti akan menggunakan teknik wawancara yang berbeda untuk masing-masing jenis informan. Untuk informan dari Kepolisian peneliti akan menggunakan wawacara langsung dan perorangan; agar informasi yang didapat bisa lebih terstruktur serta peneliti dapat mengendalikan alur pertanyaan yang ada, tanpa ada gangguan dari pihak lain; selain itu teknik jenis ini juga menegaskan kesan profesional. Serta juga dilakukan pada informan dari Kedokteran.

Di sisi lain, untuk informan dari peserta rekrutmen calon perwira perempuan yang telah dicek organ genitalianya, peneliti akan menggunakan teknik wawancara berjenis focus group. Yang mana pewawancara akan mewawancarai informan dalam sebuah kelompok. Jenis ini digunakan oleh peneliti agar keterbukaan informasi antar informan dapat lebih terbuka, berhubungan dengan memori yang mereka miliki dapat mempengaruhi kondisi psikis mereka. Namun apabila hal tersebut sulit untuk diwujudkan, maka peneliti akan menggunakan jenis wawancara perorangan tatap muka, maupun wawancara perorangan tidak tatap muka.

\section{Hasil dan Diskusi}

Peneliti mendapati 3 narasumber berbeda, yakni saudari ' $N$ ', ' $A$ ', dan ' $H$ '. Mereka merupakan calon perwira Polisi perempuan yang mengikuti agenda penerimaan Kepolisian hingga ke tahap tes kesehatan. Narasumber diwawancarai dengan metode tatap muka dan tidak tatap muka (untuk saudari $\mathrm{H}$ ), serta dalam waktu yang berbeda.

Saudari ' $N$ ' menjelaskan bahwa sebelum tes pada bagian genitalia dilakukan, ada rangkaian tes kesehatan lain, mulai dari tes dasar tubuh, penglihatan, hingga 
tanda lahir, dan tato. Saat ' $\mathrm{N}$ ' bercerita mengenai ada kemungkinan dokter laki-laki, saat ia dalam keadaan telanjang, Ia mengatakan bahwa dirinya kaget dan sedikit malu, namun Ia berusaha tetap fokus pada tes. Kemudian saudari ' $N$ ' menyatakan bahwa ia disuruh untuk menunggu agar per orang dapat diperintahkan masuk ke ruang tersendiri. Disana Ia disuruh untuk mengangkang di atas kasur, dengan 3 dokter, dan secara tiba-tiba kemaluannya dipenetrasi oleh benda asing. Hal itu terjadi sangat cepat dan menyakitkan, ucap saudari ' $\mathrm{N}$ '.

Saudari 'A' juga menceritakan hal yang sama seperti saudari ' $N$ ', dimana awalnya Ia diperintahkan untuk tes tubuh dengan mengecek seluruh badan, dan kemudian satu per satu dimasukkan ke ruangan terpisah untuk diperiksa 'vagina' nya. Dalam proses wawancara, saudari 'A' terlihat cukup tidak nyaman, sehingga Peneliti tidak melanjutkan pertanyaan.

Terakhir, saudari ' $\mathrm{H}$ '. ' $\mathrm{H}$ ' mengatakan bahwa dirinya tidak tahu akan ada pemeriksaan pada bagian genitalia, sehingga membuat dirinya sangat terkejut pada saat itu. Sebelumnya, Ia mengira bahwa tes ini sudah tidak ada, hal ini didapat dari pengakuan temannya, yang mengklaim pernah mengikuti tes ini di Jawa Tengah. Saudari ' $\mathrm{H}$ ' sendiri tidak memberikan pengalaman yang rinci pada saat kronologis pemeriksaan, namun ' $\mathrm{H}$ ' mengatakan pada peneliti bahwa, oleh dokter vaginanya dimasukkan sebuah alat yang sebelumnya telah dilumuri oleh gel. Alat ini bisa jadi merupakan sebuah Spekulum, namun kepastiannya tidak dapat peneliti buktikan. Usai melakukan tes, ' $\mathrm{H}$ ' bercerita bahwa ada temanya yang setelah melakukan tindak 'pengecekan', langsung jatuh pingsan sementara rekan polisi bersikap acuh. Setelah temannya bangun, Ia lalu kembali diperintahkan untuk berbaris. Pada akhir rentetan tes, dan diberikannya pengumuman, ' $\mathrm{H}$ ' mengatakan bahwa ada salah satu temannya yang gagal lolos, yang penyebabnya dinilai oleh ' $\mathrm{H}$ ' karena temannya tersebut sudah tidak perawan.

Selain daripada calon perwira polisi, peneliti juga mewawancarai seorang dokter di bidang Obsetriks dan Ginekologi dalam melihat penelitian ini. Yaitu dr. Tri Gunawan SpOG. Dokter Tri menyampaikan bahwasanya, pada tes Obsgyn, semua tes harus disetujui oleh pasion, tanpa terkecuali. 
Tes pertama yang biasa dilakukan oleh dokter biasanya adalah melihat secara observatif pada tubuh pasien, genitalia, paha, bokong, hingga perut, untuk menilai adakah anomali pada organ-organ tersebut. Selanjutnya dokter akan melakukan inspeksi dengan sentuhan disekitar mulut vagina, perut dan paha, hal ini sekali lagi untuk dapat mendiagnosis dengan seksama. Untuk tes organ dalam genitalia, dokter menyampaikan bahwa dapat dilakukan dengan dua tes, Spekulum, maupun USG.

Dokter Tri menyampaikan bahwasanya tes spekulum cukup beresiko pada pasien yang belum menikah, karena dikhawatirkan proses masuknya spekulum dapat merobek selaput dara. Sehingga untuk yang belum menikah ditekankan dengan tes USG.

Peneliti juga mendatangi pihak Kepolisian untuk berdiskusi pada masalah ini, namun pihak kepolisian menyatakan sikapnya yang tertutup dalam membahas tes genitalia, karena mereka mengklaim informasi atas tes ini bersifat rahasia dan bukan untuk umum.

Di Indonesia, konsep keperawanan amat sangat tertanam pada nilai dan kultur masyarakatnya sehingga mudah sekali untuk mengekang seseorang (khususnya perempuan), dengan keperawanan, atau hymennya. Seseorang bisa saja tidak diterima kerja, tidak dinikahkan, hingga dipandang buruk oleh masyarakat hanya karena hymennya sudah tidak utuh. Hal ini dapat dilihat seperti beberapa isu serta fakta mengenai diharuskan keperawanan pada perempuan untuk menjadi seorang pramugari maskapai ternama, menjadi calon istri dari anggota militer, hingga menjadi anggota militer, serta pula konon untuk menjadi anggota polisi diharuskan untuk memiliki hymen yang masih utuh.

Dimensi mengenai pentingnya hymen ini sendiri terjadi secara terstruktur, sistematis, dan mengakar, sehingga banyak orang tidak menyadari telah 'terdisiplinkan' oleh norma. Sebenarnya menaati norma bukanlah hal yang buruk, namun apabila sebuah norma terlalu diagungkan dan sifatnya pun berubah menjadi diskriminatif dan tidak lagi substantif, maka norma jenis apa yang sebenarnya sedang kita taati. 
Kecenderungannya, yang kita taati saat bicara 'keperawanan adalah simbol moralitas' adalah ego maskulinitas kita yang telah tertanam sejak lama. Seyogyanya kita tidak dapat melihat dan menyaksikan realita dimana laki-laki dan perempuan memiliki derajat yang sama, khususnya pada faktor-faktor yang tabu semacam seksualitas. Foucault sendiri menuliskan bahwa pada era Viktoria ada distingsi yang tajam antara seksualitas laki-laki dan perempuan, dan distingsi ini tidak hanya berputar mengenai aktifitas seksual, namun juga bagaimana cara berpakaian hingga berperilaku di tempat umum, dan pada orang asing.

Hal ini didasari atas hadirnya hymen sebagai alat pengekang. Lingkungan kita melihat bahwa moralitas perempuan terdapat pada selangkangannya, di hymennya. Sehingga untuk menjaga keutuhannya, lingkungan merasa bertanggung jawab untuk membungkam perempuan agar terhindar dari aktifitas-aktifitas yang dapat merusak keutuhan hymen (aktifitas seksual). 'Penjagaan' dari lingkungan sendiri sifatnya sangat koersif-preventif, dengan membungkam perempuan atas kebebasan terhadap tubuh sendiri. Perempuan diwajibkan untuk berpakaian tertutup, tidak terlalu vulgar, tidak genit, tidak aktif secara seksual, dan masih banyak lagi tidaktidak lain yang ditepatkan pada perempuan.

Seperti yang telah dikemukakan di hasil penelitian, bahwa tes genitalia merupakan rangkaian dari tes kesehatan dan bukannya tes yang berdiri sendiri. Tes ini dilakukan dengan prosesi yang cukup sama dari narasumber satu dengan narasumber lainnya, dan juga dengan narasumber yang berasal dari HRW.

Tes genitalia dimula dengan tes tubuh seperti yang diutarakan saudari ' $\mathrm{N}$ ' dan ' $A$ ', dimana calon Polisi diwajibkan untuk membuka bajunya dengan hanya menggunakan celana dalam. Tes ini dilakukan dalam satu ruangan yang dipenuhi kurang-lebih 20 orang, yang kemudian dokter akan memeriksa tubuh calon polisi, seperti payudara, hingga paha.

Setelah dari tes tersebut, kemudian calon polisi wanita akan dibariskan dan akan dimasukkan ke dalam sebuah ruangan sendiri. Saudari ' $N$ ', 'A', dan ' $\mathrm{H}$ ' menjelaskan bahwa pada masa ini, tes dilakukan di atas sebuah kasur khusus yang ditemani oleh beberapa dokter. Dari wawancara yang dilakukan oleh narasumber HRW serta saudari ' $N$ ', 'A', dan ' $\mathrm{H}$ ', menjelaskan bahwa pada ruangan itu vagina 
calon polisi akan diperiksa dengan cara memasukkan sebuah alat yang sebelumnya dilumuri oleh gel (pada wawancara dari HRW, penetrasi dilakukan oleh jari). Penetrasi ini berlangsung sebentar yang kemudian setelahnya calon polisi dipersilahkan keluar ruangan.

Sebenarnya tes pada bagian genitalia memang membutuhkan penetrasi dari luar ke dalam liang vagina, baik dengan alat maupun tidak. Namun maksud dari penetrasi pada proses tes genitalia ini pun tidak begitu jelas, apakah demi menjalankan tes PAP, atau, seperti apa yang diklaim HRW, merupakan sebuah rangkaian dari tes keperawanan.

Peneliti sendiri tidak dapat menentukan tes apa yang sebenarnya dilakukan, karena semua narasumber yang telah mengikuti tes, mengaku tidak mengingat jelas bagaimana proses penetrasi itu terjadi. Namun seperti apa yang disampaikan oleh dokter Tri, bahwa tes yang dilakukan dengan penetrasi menggunakan spekulum biasanya dilakukan untuk mengecek organ dalam genitalia perempuan. Namun tes ini merupakan tes yang beresiko karena dapat merusak keutuhan selaput dara pasien. Apabila memang seperti itu adanya, berarti Kepolisian Republik Indonesia secara terstruktur melakukan sebuah upaya 'perusakan' pada tubuh perempuan.

Hal lain yang patut disampaikan adalah, dari kedua narasumber, tidak ada yang menyebutkan mengenai pemeriksaan hernia. Padahal pemeriksaan hernia juga wajib dilakukan sebagaimana yang tertulis di dalam draft peraturan Kapolri. Namun pada kasus ini, peneliti menduga bahwa 'tes' terhadap genitalia kemungkinan dilakukan dengan cara observasi mata, tanpa perlu melakukan diagnosis dengan cara meraba.

Kebanyakan calon polisi wanita yang telah melakukan tes genitalia merasakan perasaan tidak nyaman, takut, hingga memandang pengalaman tersebut sebagai sesuatu yang mengerikan. Lingkungan yang tidak terlalu ramah (seperti yang diutarakan saudari ' $\mathrm{N}$ ' dan ' $\mathrm{H}$ '), serta prosedur yang menyakitkan sekaligus memalukan menjadi alasan mengapa proses tes genitalia ini mendapat citra yang buruk oleh publik.

Relevansi diadakannya tes ini pus sifatnya sangat abu-abu. Peneliti tidak mengatakan bahwa tes ini tidak berfaedah, melainkan menyatakan bahwa kejelasan 
untuk apa serta apa saja yang sebenarnya dilakukan pada tes genitalia menjadikan tes ini dapat dipertanyakan fungsi dan substansinya. Keseluruhan tes genitalia, seperti yang dinyatakan oleh AKBP Nariyana serta ibu Tien Abdullah, adalah demi mengecek kesehatan calon perwira. Polisi akan memilih anggotanya yang sehat secara fisik dan rohani. Namun, masalah muncul pada pembahasan mengenai tes Obsgyn serta penggunaan metode penetrasi ke dalam vagina perempuan.

Polri beriskukuh untuk menutupi SOP dari tes genitalia, yang salah satunya adalah tes pada Obsgyn. Sehingga menyebabkan apa yang saja perihal yang dites pada tes Obsgyn tidak dapat diketahui oleh khalayak. Sehingga memunculkan isuisu yang berkembang bedasarkan pengalaman calon polisi. Banyak yang menilai bahwa salah satu prosedur dalam tes Obsgyn adalah virginity test, namun polisi mengelak dari tuduhan itu dengan menyatakan bahwa Polri tidak menggunakan tes keperawanan pada proses penerimaan perwira barunya.

Dari paragraf terkahir di atas, peneliti menemukan sebuah masalah baru dari perkembangan penelitian ini. Seyogyanya, institusi negara wajib untuk bersikap transparan pada hal-hal yang menyangkut publik. Namun pada kasus tes genitalia ini, Kepolisian berdalih bahwa tes penerimaan perwira baru kepolisian adalah hal yang privat bagi instansi.

Intransparansi ini akan menjadi sebuah masalah lanjutan mengingat banyaknya masyarakat yang ingin bergabung dengan angkatan Kepolisian. Bedasarkan wawancara yang dilakukan oleh Liputan6.com, Brigjen Dedi Prasetyo, selaku Humas Polri, menyampaikan bahwa angota Polri secara keseluruhan ada pada angka 462 ribu personel, yang membuat angkatan Kepolisian Indonesia menjadi yang terbesar kedua di dunia setelah Tiongkok (2019). Banyaknya personel Polri dapat menandakan, bahwasanya masyarakat memandang Kepolisian sebagai sebuah instansi yang dapat dipercaya dan layak untuk dijadikan jenjang karir. Namun, hal ini tidak senada dengan sikap Kepolisian yang cenderung sekretif.

Peneliti tidak menekankan bahwa Kepolisian harus transparan pada segala hal termasuk informasi intelijen hingga data lainnya, tidak. Peneliti menekankan bahwa Kepolisian harus terbuka, dan transparan kepada masyarakat, pada pokok-pokok 
yang berkaitan secara langsung kepada hidup masyarakat. Seperti halnya keterbukaan pada tes genitalia.

Atas dasar ini, tes genitalia yang dilakukan pada organ intim seseorang, memaksa Polri harus membuka diri untuk mengatakan apa saja yang nantinya diperiksa, bagaimana prosedurnya, hingga apa dampaknya. Dengan bersifat tertutup, Kepolisian membiarkan isu-isu negatif bertebaran mengenai tes ini dan nantinya akan merubah persepsi masyarakat. Seperti halnya saudari ' $H$ ', yang mengklaim bahwa dirinya tidak tahu akan diadakan tes pada organ vitalnya saat mendaftar menjadi anggota Kepolisian; dan saat ternyata Ia tahu dan dihadapi pada kenyataan bahwa Ia harus melakukan hal tersebut, membuat dirinya amat sangat kecewa. Dan hal ini juga terjadi pada saudari ' $\mathrm{N}$ ', dan ' $\mathrm{A}$ ' ataupun saudari perempuan lain di Indonesia.

Lepas dari hal itu, muncul sebuah isu di masyarakat mengenai anggapan bahwa tes genitalia pada perempuan di Kepolisian merupakan tes keperawanan. Hal ini didasari pada dilakukannya penetrasi ke dalam lubang vagina perempuan, yang dianggap adalah upaya melihat keutuhan hymen pada perempuan. Isu ini diperparah ataupun diperluas dengan statement-statment di media.

Pemberitaan mengenai tes keperawanan di Polri dipopulerkan oleh media yang menyoroti tes tersebut, mulai dari HRW selaku organsisasi hak asasi, media massa, hingga media pribadi berupa individu. Menyusul keterbukaan media, menjadikan penyaringan informasi sedikit terhambat maupun dikesampingkan; sehingga banyak khalayak tidak melihat berita secara utuh. Dan hal ini kemungkinan terjadi pada isu tes genitalia di Polri ini.

Kepastian mengenai isu ini tidak ada yang tahu pasti benar atau tidanya, selama Polri berisfat intransparan, semua indikasi-indikasi yang menunjukkan adanya tes keperawanan di kepolisian, khususnya pada saat penerimaan anggota perwira barunya, masih dapat dipertanyakan dan didiskusikan.

\section{Kesimpulan}

Penelitian ini menelisik keberadaan tes genitalia di Kepolisian Republik Indonesia. Yang mana, pada laporan HRW di tahun 2014 menyatakan bahwa 
Kepolisian Republik Indonesia menggunakan tes keperawanan pada saat penerimaan anggota polisi wanita baru. Yang mana tes itu bersifat degradatif serta diskriminatif terhadap perempuan. Temuannya, dari ketiga narasumber peneliti, semuanya mengakui bahwa pada tes genitalia organ vagina mereka dipentrasi menggunakan sebuah alat oleh tim dokter. Alat ini bisa jadi merupakan sebuah spekulum, yang mana alat familiar di dunia Obgyn, yang digunakan untuk melihat fisik dalam organ intim perempuan, hingga diklaim dapat juga dipakai untuk mengecek keutuhan hymen. Dan bedasarkan pernyataan dr. Tri, seorang spesialis di bidang Obsgyn, penggunaan spekulum sebenarnya beresiko karena dapat merusak keutuhan selaput dara pasien.

Tuduhan mengenai tes ini dibantah oleh Kepolisian, bahwasanya tidak ada tes keperawanan pada tes Penerimaan Anggota Polisi baru. Tes genitalia, sesuai dengan klaim, mereka digunakan Kepolisian untuk melihat kondisi kesehatan alat vital calon perwira, bukan untuk melihat apakah calon perwira masih perawan atau tidak. Namun, Kepolisian tidak dapat membuktikan lebih lanjut bahwa memang tidak ada tes keperawanan di Instansi mereka, dengan menutupi SOP tes genitalia kepada publik.

Dengan begitu maka isu mengenai tes keperawanan di Kepolisian menemui jalan buntu, dimana semua pihak tidak dapat membuktikan apa yang mereka klaim sebagai sebuah kebenaran. HRW dan media lain tidak dapat membuktikan bahwa benar ada praktik tes keperawanan di Kepolisian, selama SOP tes genitalia tidak dipublikasikan. Sebagaimana pula Kepolisian tidak dapat meluruskan isu tes keperawanan di instansinya selama, sekali lagi, SOP tes genitalia tidak diinformasikan kepada khalayak. Selain itu, penggunaan Spekulum pada tes obsetriks dan ginekologi pada proses penerimaan Perwira baru, dinilai sangat merugikan calon perwira.

Bedasarkan apa yang telah dijabarkan pada penelitian ini, mulai dari penjelasan masalah, penggunaan teori sosial, hingga temuan di lapangan serta analisis peneliti. Maka seyogyanya, agar penelitian ini dapat menjadi lebih bermanfaat, peneliti mengajukan beberapa saran yang kemungkinan dapat diaplikasikan oleh pihak terkait. 1. Masyarakat diminta untuk dapat lebih pandai 
dalam menganalisis keberadaan norma yang ada. Mempertahankan norma merupakan hal yang baik, karena norma berisi dari nilai-nilai sosial yang telah ada di masyarakat kita; namun beberapa norma sudah dipergunakan terlewat batas hingga sifatnya tidak lagi mengatur namun juga mengekang. Dan hal ini terjadi pada norma kita mengenai konsep 'keperawanan'; 2. Kepolisian Republik Indonesia merupakan garda negara dalam menjaga keamaan NKRI. Fungsinya yang vital serta dipercaya oleh masyarakat, menjadikan POLRI sebuah instansi yang populer. Kepopulerannya ini lantas menggiring banyak masyarakat yang ingin ikut andil serta dalam Kepolisian. Namun isu tes keperawanan, yang telah lama menghantui POLRI harus dengan cepat dientaskan. Peneliti mensugesti Kepolisian agar bersifat terbuka dalam proses penerimaan perwira baru, yaitu adalah dengan memberikan akses kepada publik untuk melihat bagaimana Prosedur yang dilakukan pada tes genitalia, agar tidak ada miskonsepsi mengenai tes Obsgyn di Penerimaan Polisi Baru di Indonesia; 3. Kepolisian sudah saatnya tidak menggunakan spekulum pada saat 'tes genitalia' atau prosesi upaya penetrasi lain, dengan berubah menggunakan metode USG.

\section{Referensi}

Cinthio, H. (2015). "You Go Home and Tell That to My Dad!": Conflicting Claims and Understandings on Hymen and Virginity. Jurnal Sexuality \& Culture, NO. 19 (172189).

Creswell, J. W. (2017). Qualitative Inquiry \& Research Design Choosing Among Five Approaches. 2nd Edition. Thousand Oaks: Sage Publication, Inc.

Foucault, Michel. (2012). Discipline and Punishment: the Birth of the Prison. 2nd Edition, translated by Alan Sheridan. New York: Vintage Books.

Foucault, Michel. (2017). Wacana Kuasa/Pengetahuan. Edisi pertama, terjemahan Yudi Santosa. Yogyakarta: Narasi Pustaka Promothea.

Hikmawan, M. D. (2014). Politik Perbedaan : Demokrasi dalam Paradoks. Universitas Gdjah Mada.

Hikmawan, M. D. (2017a). Pluralisme Demokrasi Politik di Indonesia. Journal of Governance, 2(2), 223-247. https://doi.org/http://dx.doi.org/10.31506/jog.v2i2.2678

Hikmawan, M. D. (2017b). Politik Perbedaan: Minnoritas dalam Implementasi Kebijakan. Journal of Indonesian Public Administration and Governance Studies (JIPAGS), 1(1), 88-98. 
HRW. (2014). "Indonesia: Hapus 'tes keperawanan' untuk Polwan" Diakses melalui https://www.hrw.org/id/news/2014/11/17/264612 pada Selasa, 11 Juni 2019 pukul 13:42 WIB.

HRW. (2017). "Indonesia: Tes Keperawanan Masih Terus Berlanjut" Diakses melalui https://www.hrw.org/id/news/2017/11/22/311756 pada Selasa, 11 Juni 2019 pukul 13:43 WIB.

Kamm, E. (2016). Dimensions of Honour in Kremo Kartli, Georgia: The Importance of Virginity in The Name of Honour. Jurnal Staten and Legal Practice in The Caucasus, (83-94).

Phisicians for Human Rights. (2015). Tes Keperawanan dan Selaput

Dara: Tidak Ada Basis Fakta, Ilmiah atau Medis. New York: PHR.

Romero, R. (2008). The Role of Matriarchies and Patriarchies in Social Evolution Vis-A-Vis Bachofen and His Influence on the Social Sciences. Thesis Master of Science in Sociology. Texas: A\&M University Texas.

Suryakusuma, Julia. (2012). Agama, Seks, dan Kekuasaan: Kumpulan Tulisan (19792012). Depok: Komunitas Bambu. 